\title{
The Theoretical Field of Education Policy: Characteristics, Objects of Study, and Mediations. A Latin American Perspective
}

\author{
César Tello ${ }^{1,2,3 \text {,* }^{*}}$ \\ ${ }^{1}$ Department of Education, National University of Tres de Febrero, Argentina \\ ${ }^{2}$ Department of Research and Development, National University of Tres de Febrero, Argentina \\ ${ }^{3}$ Latin American Network of Epistemological Studies in Education Policy (ReLePe) \\ *Corresponding author: ctello@untref.edu.ar
}

Received March 05, 2014; Revised March 11, 2014; Accepted March 26, 2014

\begin{abstract}
This paper, of a theoretical nature, analyzes the main characteristics that the theoretical field of education policy has taken in the reality of the studies developed in Latin America during the last sixty years, analyzing its epistemic constitution under the Epistemology of Education Policy Approach and describing the main theoretical outlines of the scientific production development in education policy since 1950. From this theoretical thread, a number of theoretical analyses which allow for reflection upon the mutation of the field and the various knowledge production modes that took place during the last twenty years in the Latin American region are displayed and some reflective notes are introduced in order to discuss several knowledge production modes in education policy developed from the connection that had notably began in the nineties between academic researchers and decisionmakers.
\end{abstract}

Keywords: education policy researchers, theoretical field, objects of study, knowledge production, Epistemologies of Education Policy

Cite This Article: César Tello, "The Theoretical Field of Education Policy: Characteristics, Objects of Study, and Mediations. A Latin American Perspective.” American Journal of Educational Research, vol. 2, no. 4 (2014): 197-203. doi: education-2-4-4.

\section{Introduction}

This paper, of a theoretical nature, aims to introduce some conceptual reflections under development in the framework of what is referred to as the Epistemologies of Education Policy [34,36,38]. Through the Epistemologies of Education Policy Approach (EEPA), theses reflections intend to suggest a plan of analysis for the research field of education policy as a theoretical field, with elements that the researcher believes contribute to the meta-analytic reflection of the field.

The premises assumed on this paper are, on the one hand, considering that education policy as a theoretical field is defined through the perspective and epistemological positioning of the person who interprets/characterizes it and, on the other hand, that that definition from a specified epistemological positioning responds to an episteme of epoch in terms of Foucault. What is meant by this is that there are no universal characterizations of education policy as a theoretical field or of its object of study. Given that the object of study of education policy is built in a non neutral way, the historical development of the theoretical field and the context in which the object of study of education policy is outlined, define "new" objects of study or changes the existing one by way of what Khun called the paradigm.
All in all, these matters will be put forward along the development of this paper, but not as isolated sections but rather as horizontal axes that allow for reflection and observation of the epistemic complexity faced by the characterization of the field, the object of study of education policy and knowledge production in the field.

\section{Approach to the Epistemologies of Education Policy}

The Epistemologies of Education Policy Approach, EEPA, is made up of three elements: the epistemological perspective, the epistemological position and the epistemethodological approach (For further development and depth on these concepts, refer to [34-42]).The "Epistemologies" category is used in plural here since there are a number of epistemological positionings and perspectives to develop and carry out education policy research, i.e., there are several epistemologies in education policy as a theoretical field. On the basis of this premise and in a relational way, it can be pointed that depending on the different epistemologies, there will be various objects of study selected for analysis.

In this article, just the first two elements of the EPPA are considered in order to present ideas, assuming that the Epistemological Perspective in education policy research 
means the worldview adopted by the researcher in order to carry out their inquiries; we refer to the General Theory in terms of [21]. Examples of perspectives may include: Marxism, neo-Marxism, structuralism, post-structuralism, existentialism, humanism, positivism and pluralism.

On the other hand, the Epistemological Positioning emerges from the Epistemological Perspective itself, or should emerge in a consistent and sound research. The Epistemological Positioning, i.e. the Substantive Theory [21], as it is understood in this paper, relates particularly to the object of study, that is, to the theoretical strands typical of the field, considering that substantive theories are those which directly relate to the empirical and theoretical content of the research's data. This is the focal point and the ribs of the EEPA, since it is in this point that the researcher's worldview is at stake; worldview meaning "a set of presuppositions (assumptions) that we hold about the basic constitution of reality” ([32], p. 17). That is, not only ways of reading the reality, but also ways of building it in terms of epistemological reflexivity. In this sense, the epistemological positioning becomes the researcher's political and ideological position that relies on their choice of epistemological perspective, with which research will be conducted. Among the positionings, we may find: new institutionalist, institutionalist, legal, political constructivist, complexity, eclectic, post-modern, postmodernist, hyper-globalist, skeptical, neoliberal, transformational approach, functionalist, critical, radical critical, critical-analytical, resistance theorists, criticalreproductivist, humanist, economicist, etc.

Several studies reveal that there is no researcher's "empty head" (The "empty head" category is understood here as the position of a researcher who considers themselves as tabula rasa at the moment of beginning the research process). and various methodological terms have been used to name this issue, for instance: "researcher's assumptions" or "meaning anticipation” [33], among others. In short, the epistemological positionings and perspectives do not emerge from an "empty head," on the contrary, they have substance and support. The difficulty arises when the education policy researcher cannot name what is happening to them as epistemological perspective or positioning and tries to build their research from pseudo-neutrality, it is in that same line that they assume the object of study of education policy as a fossilized object.

Thus, [17] holds that object observation cannot be separated from the observing device. This assumes an object and a subject who knows it from within. That is, from our EEPA proposal, the object is not understood as a neutral entity, isolated from its context, where the researcher is not involved, but rather assumes a mutual involvement as starting point, what in terms of [16] would be "involvement with and detachment from" the object of study, and it is at that moment that the object "is selected." The isolation, construction and design of an object of study of education policy are carried out from an epistemological positioning. In this way, the intellectualist assumption of modern epistemology which assumes the reality as reflected in a mirror is excluded. [29]

That is why the epistemological assumption of reflexivity supposes the interaction between the subject, who begins their research from an epistemological positioning and perspective, and the object to be investigated, where subjectivity is understood as a constituent and builder of reality and knowledge, involved in a rhizomatic fold.

\section{Education Policy as a Theoretical Field}

The first conceptual clarification is provided with the objective of distinguishing studies on Education Policy (what is referred to as the theoretical field or the epistemologies of education policy) and Education Policies (those that refer to management, decision making and political action). [47] in "El político y el científico" (The politician and the scientist), emphatically held the clear differentiation between the "adoption of a political position" (Education Policies in plural) and the "scientific analysis of political phenomena" (Education Policy in singular).

Furthermore, it is necessary to analyze a widely used definition (at least in the West hemisphere) that relates to the Anglo-Saxon influence on the field of public policies in general, namely the politics and the policies, but, for non English-speaking individuals, these are categories, as [12] states "in which, the sense of the second term cannot be retrieved unless sectorial policies are specified.” (p. 3). Therefore, confusion arises when attempting to define education policies from these categories in the regions that require a translation (this is the case for Spanish-speaking countries in Latin America; these categories can neither be translated into Portuguese, French, German or Italian).

This is not a minor issue for the ones who attempt to analyze and study the theoretical field of education policy, as [[15], p. 33]: "the absence of differentiation between 'politics' and 'policy' in a number of languages, causes a big problem in the analysis of policies development in many countries. At the same time, this missing difference shows neglected realities and assumptions in policies' analysis $[\ldots] . ”$

In short, taking the field's history into account, it should be considered what in USA was called the "approach to the analysis of public policies" from what Lasswell called the knowledge of policy processes, arising in the postwar years in this country, with the work of the author in 1951, edited by Lerner and Lasswell in 1951 with the title: "The policy sciences: recent developments in scope and method." All in all, for theoretical-analytical purposes, it can be pointed that the use of "politics" and "policies" as used in USA and Great Britain, and some countries like France and Germany (though in these countries, the category is vague because of its translation) can cause serious difficulties if these issues are not explained and discussed in non English-speaking countries.

Besides, it is worth considering that the epistemologies of education policy are "nearer" to what is understood as the "approach to the analysis of public policies" in its analytical perspective rather than in its normative definition. This is of paramount importance since it allows us to define, analyze and observe the theoretical field of education policy, in terms of Bonetti (in press), from an ethnocentric cultural perspective, and that analysis will be hindered in epistemological terms by a language issue.

For the purposes of the ideas rendered in this paper, the researcher defines education policy (in singular) as the theoretical field and the education policies (in plural) as 
the socio-political reality to be analyzed, inquired, investigated. That is to say, education policies are the object of study of education policy. In this sense, it is vital to take Ana Vitar's warning [45] into account, when she states that: "We should not confuse political and social processes with the tools used to think about them.” (p. 26)

The field of education policy is defined here as a theoretical field equivalent to the academic field in terms of [4], insofar as from that field, knowledge (research) is produced, knowledge circulation (academic training) is triggered and use or application of such knowledge is developed (profession as political decision making), considering that these three spaces are not necessarily consecutive.

We can think of the possibility of defining some features of the epistemologies of education policy, but never consider that the "theory of education policy" could be defined, the latter meaning an epistemological reduction, since the current epistemological arguments do not demand "demarcation" between disciplines; that rather responds to classical studies and conceptions in the epistemological field that, for instance, distinguished between: Science-Pseudoscience-Disciplines, entering in the fake path of scientism; on the contrary, in this paper, the researcher assumes, in [46] sense, a position in favor of science and knowledge and against scientism.

It should be considered that education policy field internal regulations are structured in some way on the basis of their relation to other fields of study, and that is where the epistemologies of education policy (using a term that appears to be contradictory) in its original state are to be found, and it is said "that appears to be contradictory" because its "original state" as a field relates to its connection to complex fields. In this way, the field of education policy is considered as a reticular space, insofar as a field of knowledge is defined from a contemporary epistemology as the possibility of new conceptual constructions that allow for numerous and reciprocal interactions between different fields of knowledge. In terms of [20]: "The reticle has a doubly complex structure, given that in the lattice, elements that are in themselves lattices are admitted" (p. 79). Thus, we could think of Deleuze rhizome perspective to define the field of education policy, insofar as the fluency of any part of the rhizome can join another part, as well as more or less complex modes to understand the field.

\subsection{Objects of Study of Education Policy and Episteme of Epoch}

In order to define the object of study of education policy, the epistemological positioning and perspective categories must be adopted in opposition to the demarcational epistemological arguments, thus, the definition of episteme of epoch in terms of Foucault is assumed, mainly as regards education policy as a teaching and content transmission space. In this sense, [10] explains: "It is not Foucault's intent to present the way in which the history of a given discipline turns out to be intelligible from the meaning tradition that inspired it from its founding acts, on the contrary, he aims to show that its emergence conditions respond to historical conditions of possibility that, on the one hand, are common to all or several bodies of knowledge of an epoch, and on the other hand, change from one epoch to another.
Under the episteme notion, knowledge is not analyzed from its rational form perspective or objectivity, but from the point of view of the discontinuous homogeneity that governs the formation of different discourses that belong to the same epoch". (p. 4).

It is in this line of analysis that the object of study of education policy is defined by its episteme of epoch, understanding that the object of study of education policy is just a contextual and historical construction.

The episteme of epoch may be observed in the various lines adopted by different countries when studying education policies, e.g.: Great Britain's political sociology, USA's politics and policies, the most traditional French strands in Education Management and Politics studies, or the latest conceptual developments in the sociopsycoanalytical perspective on education policy research or what on the French strand has been called the sociology of public action or cognitive analysis, that, in a way, begins to supersede traditional studies focused on the State. Pluralistic perspective analyses can also be seen in other studies [43] like [11]; [25,26,27]; [6,7,8]; [30] productions.

Thus, the impact of these strands on the field should be considered. In a brief historicization, as a historical outline of the field of study of education policy, it could be stated that the foundational milestone of political science registers in 1948: at the request of UNESCO, experts and scholars meet in Paris in order to attempt the redefinition and delimitation of its object of study. After deliberations, the famous "List of subjects and fields of investigation" was produced under a strong influence of Anglo-Saxon thought. Although the list is just a pragmatic enumeration of subjects, sixty years after its creation, it continues to be a benchmark for the formulation of theoretical frameworks and university curricula in relation to political science, including the curricular area in current education policy in pedagogy and education degree courses in Latin America.

It is from this date onwards, that political science as an object of study with "scientific aspiration" begins to be developed in several Latin American universities, and almost exclusively, from a legal-institutionalist approach [3].

As a result of the end of Second World War, welfare policies focused on issues like health and education were developed. Thus, the incipient emergence of a new way of conceiving public policies is observed in Latin America. Considering the deployment of welfare policies, governmental organizations turned to social science researchers looking for solutions to issues posed by state activities, including those related to the growth and reform of the education system, i.e., as it was stated earlier, Laswell's pragmatic perspective.

In this framework, the more political science began to develop as a field of study, the more volume and variety of subjects to study; this became a problem at the moment -which is very common in emerging fields of knowledgesince it entailed a great effort in order to set a coherent logic in a growing number of subject matters that the field should study, but that opening effort [4] would in some way give rise to education policy as an incipient space emerging -from the historical-epistemological perspective of the time- as a sub-discipline of political science.

Endowed with the main characteristics of political sciences, education policy emerged as a theoretical field in 
the fifties, with a strong approach focused on law making and comparative education, in some cases. The latter lacked the current epistemological development, and basically consisted of establishing legislative comparative axes between different countries and the structure of the education system, among other subjects of linear comparison, virtually decontextualized; though it undoubtedly responded to the analytical matrix of political sciences in Latin America, with a legal-institutionalist approach.

It is in this decade (1950) that in Argentina, Brazil, Chile, Mexico and Colombia, among other Latin American countries, some "institutionalization" of education policy as a field begins to be noticed through the creation of departments of education policies. It is worth mentioning that the researcher is not referring here to the beginning of political reflections on education, given that those could be tracked back to Aristotle or Plato, but rather to the "institutionalization" process in terms of [22], when they explain that when some practices are detached as specific practices, by way of the creation of a subject, a degree course, a private school or a department in the university sphere, it shows a historical process and the real presence of an institutional space that allows the circulation and production of knowledge.

\subsection{Education Policy as a Theoretical Field and its Object of Study: Education Policy Decision Making}

As it was already stated, education policies constitute the object of study of education policy, in terms of its very own socio-educational reality in its multiple dimensions; it should be considered that various epistemic approaches generate an object in constant construction [19]. That is, the angles of analysis of the socio-educational reality allow for the theoretical field of education policy to be constructed from several axes that will merge into its object, for instance, the State, jurisprudence, micropolitics, political discourse, political debates, educational governance, right to education, among others. [9], opposing to the classic definition of the object of study of education policy as a State action, explains that supporting the traditional model of the object of study of education policy is getting more and more difficult since the field is becoming increasingly congested: new relationships and forms of relationships are being established in and in relation to policy. Besides, he states that "the boundaries between state, economy and civil society are being blurred" since there is a multiplicity of voices within policy conversations and new conduits through which policy discourses enter policy thinking. As ([2], p. 11) puts it "Education and social policy within government, are now thought, influenced and done in many different sites and the education policy community is increasingly diverse and unstable" which involves a shift in the development of "relations involving mutuality and interdependence as opposed to hierarchy and independence" (Peterson, 2003, p. 1. quoted in [2]). What is meant by this is that although there are methods of analysis of education policies focused on the State, those methods and analysis approaches cannot be the "classic" ones, given the new state configuration; it will be necessary to think of new plans of analysis applicable to the State-focused analysis. Nevertheless, as explained below, the State cannot be the center of education policy in terms of research, but just an element of mediation. Remember this statement is made in analytical terms for research purposes, i.e., State should be relativized in terms of research on education policy; meaning if education policy research focuses on State, the remaining elements of political mediations that will not be investigated shall be assumed, and vice versa, if education policy research does not focus on State, it shall be assumed as just one element of the framework.

Bearing in mind this consideration, the common characterization of the object of study of education policy as a State action in relation to the education field can be questioned in some way. And therefore, in this paper, the researcher asks: What happens when the "state action" category is too vague? What happens when:

-the object of study of education policy constitutes itself as the way in which classes' interests are to be understood in connection with capital (neo-Marxist epistemological perspective)? or

-the state becomes a supranational state (hyper-globalist epistemological positioning)? or

-an analysis of power circulation at school is attempted (critical post-structuralist epistemological positioning)?

[48] (p. 15) put forward the necessity of giving a definition of education policy assuming [23] argument in some way by summarizing politics as the product of a decision. For this purpose, the authors state:

"[...] But to reduce education policy to the sum of innumerable individual decisions, even decisions seen as partly predetermined or considerably constrained, is to ignore what in some analytical traditions would be called the power relations between different parts of the system and in others how decision-makers are positioned by different discourses".

However, it is clear that the authors try to give an operative definition in terms of organization of the field, since it is necessary to "reduce" [...] the sum of countless individual or collective decisions. The researcher's question here is why do the authors want to reduce?

The object of study of the education policy field is decision making. It is there that decisions may be observed at different levels of the education system as policy cycles in terms of [1] or complex decisions in terms of coalitions [31].

Thus, the researcher does not attempt to reduce the theoretical characterization of the object of study of education policy and assumes, as a conceptual approach dealing with the study of political decisions in the educational field, that there are political decisions at different levels of the education system and that those individual or joint decisions refer to the use of power. Therefore, it is necessary to distinguish the angles of study of this complex and rhizomatic object of study, for instance: curricular policies, teaching policies, funding policies, etc., that can be observed through the exercise of power of the government, the labor unionists, the teachers, the technicians, etc. at the micro, meso and macro-level of the education system or in their interrelation.

It should be considered that modern State's rational approach assumed political exercise and decision as a "top down” line. However, some decision making goes far 
beyond government decisions; i.e. there are decisions beyond those made by the state government.

Here is the dilemma: the object of study of education policy should be defined for field organization purposes, or it could be pointed that its definition is not possible, unless it has an operative and strategic goal, as Whitty and Edwards have stated, setting the object of study of education policy as the decisions made solely by state governments. In this paper, the researcher's position is diametrically opposed to that definition.

[48] thus explains that there is certain centrality in the study of education policies, from a specific epistemological positioning as the Public Choice, that according to the author "focuses on the analysis of institutional agreements, mainly the design of state institutions and legal and constitutional rules” ([14] p. 80). In this sense, the Advocacy Coalitions position is adopted in this paper, structure created by Paul Sabatier, that began the search of a summary of the best devices provided by top down and bottom up approaches in the implementation study, incorporating actors' roles in a better way.

[18] explain that though it is possible that Sabatier's theoretical referential should not be widely known in Latin America due to the authoritarian and linear state actions in the region, it constitutes a powerful analytical plan for the study of education policies where multiples actors in several levels of decision making exist; and, at this point, it is necessary to go back to the category of episteme of epoch to ask ourselves: wouldn't be our own style of state government in the Latin American region that leads researchers to focus on it?

[5] warn about the difficulty of understanding and analyzing education policy in a vertical way; similarly, [28] explains that the State should be understood as one more element in the complex structure of education policies. In this sense, reflecting on Sabatier's theoretical referential, [14] states that: "the unit of analysis cannot be limited to government structure but to a <political subsystem $>$. This sub-system, as part of the political system, is made up of a wide variety of public and private actors, actively involved or interested in a political problem or a controversy” (p. 82).

Thus, the complex mobility of public policies is defined here in terms of swarming. This category, which lacks a clear Spanish translation, refers to bees moving in search of a place to build the honeycomb. The bees move together, and it is virtually impossible to identify their traditional hierarchy, since the search of the honeycomb building place is not restricted to the queen's decision.

In this sense, education policies as political action have multiple actors, connections, decisions, power struggles, actions, impact, implementation, etc. Considering the swarming image, the key question here is: can education policies be defined and conceptualized? Our argument is that an answer to that question will demand the writing of several encyclopedias that will never come to an end. However, in order to build an object of study, clearly artificial and from an epistemological positioning, an epistemethodological (In [36], the epistemethodological category has been defined as the methodological moment at which the researcher chooses a methodology. 'Methodological approaches' are not considered as mere instruments, whether of data collection or analysis, but rather as a "logos method," i.e., the way of thinking the logos. Then, the researcher prefers the term epistemethodology, category in which method introduction and researcher's epistemological position merge. Although the methodological approach has an epistemology, for common use distinction purposes, the latter term: epistemethodology is preferred. That is, it must be considered that methodology becomes epistemethodology insofar as this is related to the other elements: epistemological perspective and epistemological position. By itself and, for instance, for teaching purposes, it refers to methodologies alone; with greater conceptual precision, methodology could be understood in terms of methodological techniques, techniques that are many times taught as epistemologies in some cases, and without epistemological support in some other cases. [4] (p. 62) is sharply sarcastic regarding this prevalence stating that it is taken as a "series of recipes or rules that ought to be respected in order not to know the object but to be acknowledged as an expert on the object.” Considering this warning, it is necessary that methodology in terms of research turn into epistemethodology, insofar as it constitute a consistent element of the three elements framework that make up the EEPA.) reduction may be carried out; i.e. building an object of study to research on education policies involves acknowledging the swarming reduction and, at the same time, not being unaware -at least- of the main features of swarming and of the fact that that object will not be moving any more. It should also be noted that the analytical models for education policies analysis should not be determining factors. For instance, the attempt of answering these questions: where do education policies begin? or where do they end? is, undoubtedly, a way of assuming an epistemological positioning and perspective. From a top down or bottom up point of view, for example, this entails acknowledging the beginning and end in a pseudo-positivist vertical analysis. And if education policies could be thought of as a horizontal movement in a decisions continuum, which change step by step, gradually, from the authorities of a state government to a teacher, where decision making shows changes an more changes in the disorganized development of political action, where some include and change the others?

Thus, having made this characterization, it can be pointed that an education policy researcher who aims to characterize the theoretical field and its object of study will observe the theoretical field (swarming) from an epistemological positioning and an epistemological perspective, and never with an "empty head."

Some people consider education policies as a swarm, a honeycomb, located at some place, motionless, fossilized (though the bees are working inside). On the contrary, education policies are never still. For instance, a legislative decision involves decision making, perspectives, analyses, debates among every education system actor in a spiraled development that continues as a subjective construction, an intertextual trajectory. Stephen Ball has defined education policies as text and discourse; when referring to education policies as text, the author [1] explains that they are the product of a sinuous and unexpected trajectory, generated in the context of different political arenas, through struggles, commitments, interpretations and recreations of public authority, that 
will later be decoded by the actors who, in turn, will add different meaning, making minor context adjustments in a complex way. However, in this characterization, a vertical point of view with stages is kept regarding political trajectory (policy cycles) with main and supporting actors. In the education policy proposal as intertextuality, as swarming, texts are in constant change in political action. It is at this point that confusion arises with respect to the political trajectory, i.e. between those that have greater or lesser power in government actions. What is meant by this is that power struggles are carried on, but not necessarily, won by those with greater power. The process is much more complex, given that the mutual implications between the actors with different power levels change the other actor's power in an intertextual and rhizomatic perspective. [13] defined the rhizome as a descriptive model in which the organization of the elements do not follow hierarchical subordination lines -with a base or root from which a number of branches develop, according to the famous tree model of Porfirio-, on the contrary, in this model, any element can affect and influence any other element. In a traditional tree or hierarchical model, like policy cycles taxonomies, what is asserted about the higher level elements is necessarily true about the subordinated elements, but not the other way around. In a rhizomatic model, any statement asserted about an element may influence the conception of the rest of the elements in the structure, regardless of its mutual position. Thus, the rhizome has no center.

In short, this paper aims to put forward the idea that education policies, in terms of political actions, make up a swarming-like rhizomatic intertextuality.

\subsection{Organization and Mediations of Education Policy as Theoretical Field}

As a global approach embracing several multiplicities for the characterization of the object of study of education policy, the researcher dares to consider that the political aspects in terms of decision making, facts, phenomena, events and processes derived from socio-educational reality constitute the object of study of education policy. Thus, it is necessary to define what is understood by political aspects. The position adopted in this paper stands at the beginning of humankind, when the first hominid met another hominid, they recognized themselves, agreed, confronted, defined structure, created institutions to be ruled by, represented one another, etc. In short, it is not the policies that constitute the political aspects. But certainly, the political aspects constitute the policies. The political aspects do not entail the laws, the State, the government, the school. There, the policies may be analyzed in terms of theoretical research, but without the political aspects (which are not the school, the laws, the State) policies disappear.

In order to research on the focal point of education policy as a theoretical field, i.e. on the political aspects, another issue that should be addressed is that of mediations. Mediations used to approach the political aspects may include: the school, the laws, the State, etc. That is: the political aspects in educational terms, and not the mediations, constitute the object of study of education policy.

From this perspective, the object of study of education policy as a theoretical field must be set in an episteme of epoch, which will vary along with the mediations that allow the study of political aspects, in terms of facts, phenomena, events and processes derived from socioeducational reality.

In this line of analysis, it is believed that the study of the emergence of education policy assumes some sort of agreement regarding what is assessed in the field: "Those that participate in the struggle, contribute to reproduce the game, contributing in a more or less comprehensive way depending on the fields, to produce the belief in the value of what is at stake” ([4] p. 122). This conceptualization points out the existence of a field as a set of practices, senses, regulatory mechanisms, etc. that structure themselves around the activities developed by institutions, particularly in this paper, university institutions and the actors involved within them.

However, given the above definition, it could be argued that any study or research is political, since the "political aspects" are present in human routines. Yet, for field organizations purposes, it is necessary to state at least, in terms of episteme of epoch, that there are a number of restrictions, never fixed, but porous, that in a way, and from other fields of study, determine a space for the study of the education policy field, and serve as a clearly artificial tool to agree about what is talked about and studied, something that, in knowledge organization terms, becomes mandatory for naming purposes. Thus, the theoretical field of education policy can be organized in studies on a) teaching policies, b) education funding policies c) curricular development policies d) government policies on education system e) education reform policies f) education assessment policies g) university policies h) studies on education micro-politics (ethnographic) i) policy and law making on education system j) compared education policy.

This should be understood as a mere arbitrary and organized construction carried out by the ones that make up the field as researchers.

\section{Conclusion}

One of the main contributions this paper is believed to afford relates to its contribution to the epistemological strengthening of the theoretical field, without being its aim to distinguish between science, discipline or sub-discipline, understanding that in the social field, in terms of [44], any disciplinary classification or division is, to a great extent, an arbitrary construction which does not assume an origin necessarily connected to the "nature of things" (p. 224).

On the contrary, the epistemological strengthening of the theoretical field takes place insofar as it assumes its multidisciplinarity and interdisciplinar complexity in the development of education policy research, which becomes evident in the multidimensionality of its epistemological positionings, epistemological perspectives and epistemethodological approaches with the construction of several objects of studies.

Basically being a field of the social sciences, it deploys from its own theoretical multiplicity, which does not question -from our perspective- its epistemological strength but rather places it as a solid and fertile space, given its diversity, to analyze education policies. 
In short, it is believed that numerous fields of study of education policy as a theoretical field may emerge from this characterization.

\section{Acknowledgement}

I would like to thank Jorge Gorostiaga for reading an earlier version of this paper and the useful comments and feedback he provided and Victoria Blanco by care translation.

\section{References}

[1] Ball, S. J., Education reform: A critical and post-structural approach, Buckingham, Open University Press, 1994.

[2] Ball, S., "Política social y educativa, empresa social, hibridación y nuevas comunidades discursivas", Propuesta Educativa, 2 (36). 25-34, 2011.

[3] Barrientos Del Monte, F., "La ciencia política en América Latina. Apuntes para una historia (estructural e intelectual) de la disciplina en la región.” Seminario de Investigación del Área de Ciencia Política y de la Administración de la Universidad de Salamanca. Instituto Italiano di Scienze Umane, Florencia, Italia, 2009

[4] Bourdieu, P., Los usos sociales de la ciencia, Buenos Aires, Nueva Visión, 2000

[5] Bowe, R. et. al., Reforming education y changing schools: case studies in Policy Sociology, London, Routledge, 1992

[6] Bronfenbrenner, U., "Toward an experimental ecology of human development”, American Psychologist, 32 (7), 513-531, 1977

[7] Bronfenbrenner, U., The Ecology of human development, Cambridge, Harvard University Press, 1979.

[8] Bronfenbrenner, U., "The Ecology of cognitive development: research models and fugitive findings," In R. H., Worzniak, and K. Fisher (Eds.), Scientific environments, New Jersey, Lawrence Erlbaum, 3-44, 1993.

[9] Burch, P., Hidden Markets: The new education privatization, Abingdon, Routledge, 2009

[10] Castro, E., "Michel Foucault: sujeto e historia.” Tópicos, 14, 171183, 2006, [Online]. Available: http://www.scielo.org.ar/scielo.php?script=sci_arttext\&pid=S1666 $-485 X 2006000100008 \& \operatorname{lng}=$ es\&nrm=iso.

[11] Cochran, M., The International handbook of child care policies and programs, Westport, London, Greenwood Press, 1993

[12] Cox, C., "Construcción política de reformas curriculares: el caso de chile en los noventa," Profesorado. Revista de currículum y formación del profesorado, España, 10 (1), 1-24, 2006.

[13] Deleuze, G. and Guattari, F., L'Anti-Oedipe: Capitalisme et Schizophrenie, Editions de Minuit, Paperback, 1972.

[14] Deubel, A. N., "Perspectivas teóricas para el análisis de las políticas públicas: ¿de la razón científica al arte retórico?” Estudios Políticos, 33, 67-91. 2008

[15] Dror, Y., Public Policy Making Reexamined, New Brunswick, NJ, 1983.

[16] Elías, N., Compromiso y distanciamiento, Buenos Aires, Prometeo, 1993.

[17] Espina Prieto, M., "Complejidad, transdisciplina y metodología de la investigación social.” Revista Utopía y Praxis Latinoamericana, 12 (38). 29-43, 2007

[18] Flores Crespo, P. and Mendoza, D. C., Implementación de políticas educativas: los concursos de oposición para obtener una plaza de trabajo en el marco de la alianza por la calidad de la educación, Universidad Iberoamericana, México, 2012.

[19] Galindo Cáceres, J., "Del objeto construido al objeto percibido," Estudios sobre las culturas contemporáneas, 5 (9), 9-24, 1999.

[20] Gianella, A. "Las disciplinas científicas y sus relaciones." Anales de la educación común, II (3), abril, DGCyE, 74-83, 2006

[21] Glaser, B. and Strauss, A., The discovery of grounded theory: Strategies for qualitative research, New York, Aldine publishing, 1967.

[22] Gómez Campo, V. and Tenti Fanfani, E., Universidad y profesiones. Crisis y alternativas, Buenos Aires, Miño y Dávila, 1989.

[23] Jennings, R.E., Education and politics: Policy-making in local education authorities, London, B. T. Batsford Limited, 1977.
[24] Lasswell, H., "The Policy Orientation.” In D. Lerner and H. Lasswell, The policy sciences: recent developments in scope and method, Stanford, Stanford University Press, 3-15. 1951.

[25] Muller, P., Les politiques publiques. Paris, PUF, 1990.

[26] Muller, P., "L'analyse cognitive des politiques publiques: vers une sociologie politique de l'action publique." Revue Française de Science Politique, 50 (2), 189-208, 2000.

[27] Muller, P. and Surel, Y., A análise das políticas públicas. Trad. Agemir Bavaresco e Alceu R. Ferraro. Pelotas: EDUCAT, 2002.

[28] Raab, Ch., "Theorising the governance of education," British Journal of Educational Studies, 42 (1), 6-22, 1994.

[29] Rorty, R., La filosofía y el espejo de la naturaleza, Madrid, Cátedra, 1989.

[30] Rossetti-Ferreira, M. C., Ramon, F. and Silva, A. P. S., "Políticas de atendimento à criança pequena nos países em desenvolvimento.” Cadernos de Pesquisa, 115, 65-100, 2002.

[31] Sabatier, P. A., "An Advocacy coalition framework of Policy Change and the Role of Policy-Oriented Learning Therein,” Policy Sciences, 21, 129-168, 1988.

[32] Sire, J., The Universe Next Door: A Basic Worldview Catalogue, Downers Grove, IL, InterVarsity Press, 2004.

[33] Sirvent, M. T., "Problemática actual de la investigación educativa," Revista del Instituto de Investigaciones en Ciencias de la Educación, 8 (14), 64-75, 1999.

[34] Tello, C., "Epistemologías de la política educativa y justicia social en América Latina." Nómadas. Revista Crítica de Ciencias Sociales y Jurídicas, Monográfico América Latina EMUI EuroMediterranean University Institute, España, 489-500, 2011.

[35] Tello, C., "Las Epistemologías de la política educativa y la concepción de producción del conocimiento 'basada en la evidencia'.” In N. Fernández Lamarra (comp.) Estudios sobre Políticas Educativas. EDUNTREF, Argentina, 2012 a.

[36] Tello, C., "Las epistemologías de la política educativa: vigilancia y posicionamento epistemológico del investigar em política educative,” Práxis Educativa, 7 (1), 53-68, 2012 b.

[37] Tello, C., "Las epistemologías de la política educativa.” Congreso Internacional educación, lenguaje y sociedad: "La educación en los nuevos escenarios socioculturales," La Pampa. Actas..., Argentina, 2009.

[38] Tello, C., "Política Educativa y Fraternidad en América Latina. Notas Epistemológicas.” In O., Barreneche (coord.), Estudios sobre fraternidad. Serie Política y Sociedad. Buenos Aires, Editorial Ciudad Nueva, 2010.

[39] Tello, C., “Los componentes del EEPE.” I Jornadas Latinoamericanas de Estudios Epistemológicos en Política Educativa. Conferencia Inaugural. Actas...,. Buenos Aires, UNTREF, 2012 c

[40] Tello, C., "El horizonte del Enfoque de las Epistemologías de la política educativa: la justicia social," In M. L. Almeida; L., Bonetti and T. Pacievitch $\mathrm{O}$ social e as políticas educacionais na contemporaneidade: das desigualdades à violencia no espaço educacional, Campinas, Mercado de Letras, 2013 a

[41] Tello, C., "Notas reflexivas y descriptivas sobre el enfoque de las epistemologías de la política educativa." Conjectura: filosofia e educação, Caxias do Sul, 18 (especial), 48-62, 2013 b

[42] Tello, C., "Las epistemologías de la política educativa. Notas históricas y epistemológicas sobre el campo,” In Tello, C. (org) "Las epistemologías de la política educativa. Enfoques y Perspectivas para el análisis de Políticas educativas.” Mercado de Letras, Campinas, SP, 2013 c.

[43] Tello, C. and Mainardes, J., "La posición epistemológica de los investigadores en Política Educativa: debates teóricos en torno a las perspectivas neo-marxista, pluralista y pos-estructuralista." Education Policy Analysis Archives/Archivos Analíticos de $\begin{array}{llll}\text { Políticas, } & 20 & \text { (9), } & \text { [Online]. Available: }\end{array}$ http://epaa.asu.edu/ojs/article/view/988, 2012

[44] Tenti Fanfani, E., La escuela y la cuestión social, Buenos Aires, Siglo XXI, 2007.

[45] Vitar, A. Políticas de educación. Razones de una pasión, Buenos Aires: Miño y Dávila, 2006.

[46] Wallerstein, I., Impensar las ciencias sociales, México, Siglo XXI, 1999.

[47] Weber, M., El Político y el científico, Madrid, Alianza editorial, 1991.

[48] Whitty, G., and Edwards, T., "Researching Thatcherite education policy.” In G. Walford (ed.) Researching the powerful in education: Social Research today, London, UCL Press Limited, 14-31, 1994. 